\title{
LEARNING GOOD PHARMACEUTICAL PRACTICES AS A COMPONENT OF PROFESSIONAL TRAINING OF PHARMACY SPECIALISTS
}

\author{
Aelita Krychkovska \\ Ph.D., Lviv Polytechnic National University, Ukraine \\ e-mail: aelitakrychkovska@gmail.com,orcid.org/0000-0002-0112-5003 \\ Nataliya Zayarnyuk \\ Ph.D., Lviv Polytechnic National University, Ukraine \\ e-mail: nzayarnyuka@gmail.com,orcid.org/0000-0002-5507-5873
}

Oksana Lopatynska

Ph.D., Lviv Polytechnic National University,

Danylo Halytsky Lviv National Medical University, Ukraine

e-mail: Oksana.lo@gmail.com,orcid.org/0000-0002-6952-8001

\section{Roksolana Konechna}

Ph.D., Lviv Polytechnic National University, Ukraine

e-mail: rkonechna@ukr.net,orcid.org/0000-0001-6420-9063

\section{Nataliia Polish}

Ph.D., Lviv Polytechnic National University, Ukraine

e-mail: polishn@ukr.net, orcid.org/0000-0002-1676-1053

\section{Volodymyr Novikov}

Doctor of Chemical Sciences, Head of Department,

Lviv Polytechnic National University, Ukraine

e-mail: volodymyr.p.novicov@1pnu.ua, orcid.org/0000-0001-7310-3578

\section{Summary}

The article presents the results of the analysis of alternative methods of studying the Good Pharmaceutical Practice complex, introduced at the Lviv Polytechnic National University. The optimal structure of the curriculum for student's education by the specialty 226 "Pharmacy, Industrial Pharmacy" was determined to improve the system of training of specialists, who need understand the current pharmaceutical legislation of Ukraine and prospects for its development.

Structural-and-logical schemas based on the Guidelines of Good Pharmaceutical Practices that greatly facilitate students' perception and assimilation of all the needed information have been elaborated.

The development of such schemes by students with teacher assistance allows to improve the perception of the material and strengthen skills for independently analyzing. While performing the task, students to learn and understand certain aspects, such as the fact that the quality of the medicines is "incorporated" into the drug at the stage of pharmaceutical development, and then confirmed during preclinical and clinical research. Further, the medicine receives a "permit to life", when passing state registration. After that, the specified quality is reproduced for each series at the stage of full-scale pharmaceutical manufacturing, it is maintained unchanged at the stages of storage and distribution and, finally, it is delivered to patients in pharmacies. 
The study of the possibility of mastering the discipline "Good Practices in Pharmaceutics" by students of specialty 226 "Pharmacy, Industrial Pharmacy" during the practice at the existing pharmaceutical enterprises can be considered perspective.

Keywords: pharmaceutical education, Guidelines structure, introspection.

DOI https://doi.org/10.23856/4310

\section{Introduction}

Adaptation of Ukrainian legislation to the acquis communautaire of the European Union is one of the main components of the European integration policy of Ukraine. Accordingly, the regulatory systems of the EU, Member States of EU and Ukraine should be harmonized (or compatible) concerning the pharmaceutical sector as a whole and pharmaceutical education in particular. The legislation of Ukraine and the EU should include the same terminology and implement common standards. For example, the decision to register medicines or other medical product occurs in different legislative environments, using different procedures. To resolve this issue, national legislation should include references to EU law. Ukraine is not an EU member state and this creates problems for approximation of the Ukrainian legislation to the EU law. However, the European integration processes taking place in Ukraine encourage both scientists and practitioners to implement EU legislation in all fields of the national economy.

The set of Good Pharmaceutical Practices rules, especially Good Manufacturing Practice is one of the fundamental elements of quality assurance of the process of production and turnover of medicines and other medicinal products (Pittenger, Chapman, Frail, Moon, Undeberg, Orzoff, 2016; Patel, Chotai, 2008). Implementation of rules of the Good Pharmaceutical Practices into the field of medicines turnover allows to guarantee their quality, to satisfy needs of the national health care system and each patient in quality medicines (Abdellah, Noordin, Ismail, 2015; Mitroka, Harrington, DellaVecchia, 2020). Many leading Ukrainian scientists investigate the possibility of elaboration of the Good Pharmaceutical Practices complex and structuration of the relevant legal document: Gromovyk B., Gubin Yu., Lebedynets V., Hudz N., Kalynyuk T. and others (Hromovyk, Horilyk, 2013; Lebedinets, Tkachenko, Gubin, Zborovskaya, Romelashvili, Spiridonov, 2017; Hudz, Kalynyuk, Bilous, Smetanina, 2013). However, the possibility of step-by-step teaching at the various levels of specialist training for pharmaceutical branch and the gradual study by students of the specialty 226 "Pharmacy, Industrial Pharmacy" the whole complex of Good Pharmaceutical Practices were not studied.

The research aimed involving student audience to analyze the alternative methods of studying the complex of Good Pharmaceutical Practices, introduced for educational process at the Lviv Polytechnic National University and to determine the optimal structure of curriculum for the student's education by the specialty 226 "Pharmacy, Industrial Pharmacy" to improve the system of training of specialists, who need understanding the current pharmaceutical legislation of Ukraine and the prospects for its development.

\section{Results and discussion}

The object of study involves the legislation concerning whole Good Pharmaceutical Practices complex, curriculums of medical and technical higher educational establishments in Ukraine. 
According to the order of the Ministry of Health care of Ukraine, the learning of the discipline "Good Practices in Pharmaceutics" is conducted by the credit-modular system for students at the fifth course of medical universities since 2013 (Krychkovs'ka, Zayarnyuk, Bolibrukh, 2017). The main objective of this discipline is setting in students the basic concepts of Good Pharmaceutical Practices, focusing on the main requirements of Good Practices and features of each step of the medicine life cycle: pharmaceutical development, preclinical research, clinical trials, registration (re-registration) and amendments to the registration documents, mass production, storage, wholesale and retail sale of medicines (Koster, Schalekamp, Meijerman, 2017; Pearson, Hubball, 2012; Meijerman, Nab, Koster, 2016).

The Good Pharmaceutical Practices complex and the list of legislative documents that regulate them in Ukraine are given in Table 1.

Table 1

Guidelines governing the Good Pharmaceutical Practices complex in Ukraine

\begin{tabular}{|c|c|c|}
\hline $\begin{array}{l}\text { The part of Good } \\
\text { Pharmaceutical } \\
\text { Practices complex }\end{array}$ & $\begin{array}{l}\text { Guidelines governing } \\
\text { the Good Practices }\end{array}$ & Definition of the certain Good Practices \\
\hline $\begin{array}{l}\text { Good Laboratory } \\
\text { Practice }\end{array}$ & $\begin{array}{l}\text { Medicines. Good Labora- } \\
\text { tory Practice. Guidelines. } \\
\text { 42-6.0:2008 }\end{array}$ & $\begin{array}{l}\text { Principles and rules of the organizational pro- } \\
\text { cesses and the conditions, under which preclinical } \\
\text { studies of safety for people's health and environ- } \\
\text { ment are planned, performed, inspected recorded } \\
\text { and reported as a report and archived. }\end{array}$ \\
\hline $\begin{array}{l}\text { Good Clinical } \\
\text { Practice }\end{array}$ & $\begin{array}{l}\text { Medicines. Good Clini- } \\
\text { cal Practice. Guidelines. } \\
\text { 42-7.0:2008 }\end{array}$ & $\begin{array}{l}\text { Principles and rules for designing, conducting, } \\
\text { performing, monitoring, auditing, recording of } \\
\text { clinical trials that provides assurance that the data } \\
\text { and reported results are credible and accurate, } \\
\text { and that the rights, integrity, and confidentiality } \\
\text { of trial subjects are protected. }\end{array}$ \\
\hline $\begin{array}{l}\text { Good Manufactur- } \\
\text { ing Practice }\end{array}$ & $\begin{array}{l}\text { Medicines. Good Man- } \\
\text { ufacturing Practice. } \\
\text { Guidelines. 42-4.0:2015 }\end{array}$ & $\begin{array}{l}\text { Set of rules for the organization of medicines } \\
\text { manufacturing and quality control, which is an } \\
\text { element of the quality assurance system that pro- } \\
\text { vides the stable production of medicines accord- } \\
\text { ing to the requirements of technological regula- } \\
\text { tory documentation and performance the quality } \\
\text { control by a certain method. }\end{array}$ \\
\hline $\begin{array}{l}\text { Good Storage } \\
\text { practice }\end{array}$ & $\begin{array}{l}\text { Medicines. Good Storage } \\
\text { practice. Guidelines. } \\
\text { 42-5.1:2011 }\end{array}$ & $\begin{array}{l}\text { Set of rules and requirements, that ensure the } \\
\text { quality of medicines and other medicinal prod- } \\
\text { ucts during storage and transportation at all stages } \\
\text { of their turnover. }\end{array}$ \\
\hline $\begin{array}{l}\text { Good Distribution } \\
\text { Practice }\end{array}$ & $\begin{array}{l}\text { Medicines. Good Distri- } \\
\text { bution Practice. Guide- } \\
\text { lines. 42-5.0:2014 }\end{array}$ & $\begin{array}{l}\text { Set of rules and requirements, that ensures the qual- } \\
\text { ity of medicines during management and organiza- } \\
\text { tion of their wholesale distribution at all stages. }\end{array}$ \\
\hline $\begin{array}{l}\text { Good Pharmacy } \\
\text { Practice }\end{array}$ & $\begin{array}{l}\text { On approval of the } \\
\text { Guidelines "Good Phar- } \\
\text { macy Practice. Pharmacy } \\
\text { service quality stan- } \\
\text { dards". Order Ministry of } \\
\text { Health care of Ukraine, } \\
\text { No 455, 30.05.2013 }\end{array}$ & $\begin{array}{l}\text { Set of rules and requirements for pharmacy pro- } \\
\text { fessional's activity to promote public health and } \\
\text { prevent disease, dispense and use of prescribed } \\
\text { medicines, self-medication, as well as recommen- } \\
\text { dations concerning medicines prescribing and } \\
\text { administration. }\end{array}$ \\
\hline
\end{tabular}


Lviv Polytechnic National University according to the Law of Ukraine "On Education" provides the specialists training by the three-cycle system: bachelor - master - Ph.D. student. Students training occurs by the educational-and-qualification characteristics (EQC) and educational-and-professional (EPP) and educational-and-scientific (ESP) programs, which provide theoretical, practical and scientific training, including independent research activity under the supervision of a scientific advisor and consultants from research institutes or industrial laboratories by mutual agreement on scientific cooperation and student's practical training (Hromovyk, Horilyk, 2013). The educational process of future pharmacists is carried out by the curriculum for the specialty 226 "Pharmacy, Industrial Pharmacy" approved by Lviv Polytechnic National University and provides three-cycle training, namely: 240 ECTS credits for education at the first (bachelor) cycle, 90 ECTS credits at the second (master's) cycle and 60 ECTS credits at the third (educational-scientific) cycle for the degree of Doctor of Philosophy.

The result of the conducted analysis of our curriculum showed that considerable attention is paid to the study Good Pharmaceutical Practices complex throughout the training period of future specialists for pharmacy and industrial pharmacy. Primarily, at the first (bachelor) cycle of higher education, the problems of regulatory pharmaceutical practice and distribution are considered in such disciplines as "Pharmacy Drug's Technology" (issues of Good Pharmacy Practice and Good Storage Practice), "Management and Marketing in Pharmacy" and "Legal Regulation of Pharmaceutical Companies Activity". Disciplines "Clinical Pharmacy" and "Laboratory and Functional Diagnostics", "Quality Control of Medicines", accordingly, address issues of Good Clinical Practice and Good Laboratory Practice. The questions on Good Manufacturing Practice have an important place when learning such disciplines as "Designing Chemical-and-Pharmaceutical Manufactures", "Industrial Pharmaceutical Technology" and "Modeling and Design of Chemical-and-Pharmaceutical Enterprises in GMP System". The various types of practices (technological, pre-degree, research) at domestic enterprises where Good Manufacturing Practice rules are implemented ("Arterium" Corporation, a pharmaceutical company "Darnytsia", PJSC "Pharmak", Ltd. "Ternopharm", etc.) are important for the professional and practical training of pharmacists.

However, the curriculum exactly for the third (educational-and-scientific) cycle includes a complex professional-and-oriented discipline "Good Practices in Pharmaceutics", which aims to form an integrated view on the conception of Good Practices in quality assurance of medicines; pharmaceutical development; medicines preclinical and clinical investigation; medicines registration in Ukraine; drugs manufacturing in accordance with the requirements of Good Manufacturing Practice; storage and distribution of medicines by the requirements of Good Storage Practice and Good Distribution Practice; retail trade by the requirements of Good Pharmacy Practice, etc. Consequently, the graduate of the Lviv Polytechnic National University of the third (educational-and-scientific) cycle has sufficient knowledge concerning Guidelines of Good Practices.

However, first and second cycle students need an awareness of the generalized structure. A teacher assistance in modeling approximate fundamentals for further mastering of educational materials a huge information field such as separate issues, guidelines, orders of the Ministry of Health care of Ukraine, reference book, etc. is important especially for them.

Often, the authors of the educational literature suggest to students such a principle of material presentation as simulation and scaling material, diagrams and structures for better discipline perception. Typically, each scientist offers its structure a more accessible material submission. 
In Lviv Polytechnic National University, students when studying the discipline "Good Practices in Pharmaceutics”, independently elaborate schemes of current regulatory documents that establish certain Good Practices. Fig. 1-3 show examples of Guidelines structures developed by students of specialty 226 "Pharmacy, Industrial Pharmacy" of the second cycle higher education program.

Prepare, obtain, store, secure, distribute, administer, dispense and dispose of medicine and other medical products
Provide effective medication therapy management
Maintain and improve professional performance

Contribute to improve effectiveness of the healthcare system and public health
Medicines should be prepared to comply with written formulas and quality standards for raw materials, equipment and preparation processes, including sterility.

The procurement should be supported by strong quality assurance principles.

The proper storage conditions should be provided for all medicines.

The appropriate facilities, trained personnel, standard dispensing practices, and documentation procedures are in the pharmacy for the supply and dispensing of prescribed medicines and other health-care products.

The access to an appropriate evidence base relating to the safe, rational and cost-effective use of medicines should be maintained. All necessary clinical and patient data should be used to coordinate effective medication therapy management.

Continuing education should be perceived as a lifelong process. The evidence of continuing education or continuing professional development to improve clinical knowledge, skills and performance should be demonstrated.

The educational materials should be used for health management, health promotion, and disease prevention programs.

Pharmacists should engage in preventive care activities that promote public health and prevent disease.

\section{Fig. 1. Structure of Guidelines "Good Pharmacy Practice" developed by a student of second cycle of education program Rak H.}

The development of such schemes by students with teacher assistance allows to improve the perception of the material and strengthen skills for independently analyzing, determining the essential elements and formulating conclusions about the necessary (possible) information, which is fundamental for the performance of the professional activity. While performing the task, students to learn and understand certain aspects, such as the fact that the quality of the medicines is "incorporated" into the drug at the stage of pharmaceutical development, and then confirmed during preclinical and clinical research. Further, the medicine receives a "permit to life", when passing state registration. After that, the specified quality is reproduced for each series at the stage of full-scale pharmaceutical manufacturing, it is maintained unchanged at the stages of storage and distribution and, finally, it is delivered to patients in pharmacies. Appropriate Good Practices are obligated for implementation to maintain the quality of medicines at all specified stages of drug turnover (Law, Bader, Uzman, Williams, Bates, 2019; Ten Cate, Scheele, 2007).

The pharmaceutical manufacturing requires Good Manufacturing Prctice compliance, which enables the achievement of appropriate quality, efficacy, and safety of the medicines, that laid down during pharmaceutical development and proven in preclinical and clinical trials. 


\section{QUALITY MANAGEMENT}

The maintenance of a quality system setting out responsibilities, processes and risk management principles concerning their activities

\section{REQUIREMENTS FOR}

THE PERSONAL

Competent personnel should be involved. The designation of the responsible person who meets the qualifications and all conditions provided for by the legislation of Ukraine.

Personnel should receive proper training concerning GDP. Appropriate procedures relating to personnel hygiene, relevant to the activities being carried out, should be established.

\section{REQUIREMENTS FOR} THE PREMISES AND

\section{EQUIPMENT}

Availability in establishments suitable and adequate premises, installations and equipment. The continuous monitoring of cleanliness and proper temperature.

\section{REQUIREMENTS FOR}

\section{THE DOCUMENTATION}

Clarity, readily availability, retrievability and storage in paper and electronic form.

Records should be made at the time each operation is undertaken.

\section{COMPLAINTS,}

RETURNS, SUSPECTED FALSIFIED

MEDICINAL

PRODUCTS AND

MEDICINAL PRODUCT RECALLS

Monitoring of complaints using all original details.

Compliance with the rules

of medicinal products returns by the legislation of Ukraine and contractual arrangements between the parties. Immediately returns falsified medicinal products from the supply chain and storage in a dedicated area away from all other medicinal products.

\section{OUTSOURCED} ACTIVITIES

Availability written contract between the contract giver and the contract acceptor.

\section{SELF-INSPECTIONS}

Covering all aspects of GDP and compliance with the regulations, guidelines, and procedures within a defined time frame.

\section{OPERATIONS}

Ensuring the identity of the medicinal product.

The minimizing risk of falsified medicinal products entering the legal supply chain. Inspection of medicines upon receipt of the medicinal products, an inspection of stored medicines, destruction of obsolete goods.

\section{SPECIFIC PROVISIONS FOR \\ BROKERS}

The training, proper documentation and compliance with all rules of distribution, except requirements for the premises, facilities, and equipment.

\section{TRANSPORTATION}

Ensuring the integrity of medicines and medicinal products, compliance with distribution conditions.

Fig. 2. Structure of Guidelines "Medicines. Good Distribution Practice. 42-5.0:2014”, developed by a student of second cycle of education program Dedyk $L$. 


\section{PERSONAL}

REQUIREMENTS

There should be an adequate number of qualified personnel. Personnel should receive proper training concerning good storage practice.

Observation of high levels of personal hygiene and sanitation. Providing personal with suitable protective or working garments appropriate for the activities they perform.

\section{PREMISES AND FACILITIES}

The sufficient capacity of storage areas and others premises. The ensuring good storage conditions. Medicines protection from the weather, pests and vermin. Adequate lighting. Availability of quarantine zones for temporary storage of medicines.

\section{STORAGE}

Written instructions and records should be available each delivery. Storage in containers with appropriate labelling. On receipt, medicines should be checked against the purchase order. Periodic stock reconciliation should be performed. Control of obsolete and outdated materials and pharmaceutical products.

\begin{tabular}{|c|c|c|}
\hline ACTIVITY & & \\
\hline $\begin{array}{l}\text { GOODS RETURNING } \\
\text { Maintenance and keeping } \\
\text { records of returned goods, } \\
\text { including recalled goods, } \\
\text { placement in the } \\
\text { quarantine area until } \\
\text { positive results are } \\
\text { obtained, identification and } \\
\text { registration stock. }\end{array}$ & $\begin{array}{l}\text { DISPATCH AND } \\
\text { TRANSPORT } \\
\text { Providing storage } \\
\text { conditions, the integrity of } \\
\text { the products. Availability } \\
\text { of required documents and } \\
\text { records for dispatch. }\end{array}$ & $\begin{array}{l}\text { PRODUCT RECALL } \\
\text { There should be a procedure to } \\
\text { recall from the market, } \\
\text { promptly and effectively, } \\
\text { pharmaceutical products and } \\
\text { materials known or suspected to } \\
\text { be defective. }\end{array}$ \\
\hline
\end{tabular}

Fig. 3. Structure of Guidelines “Medicines. Good Storage Practice. 42-5.1:2011”, developed by a student of second cycle of education program Nos $N$.
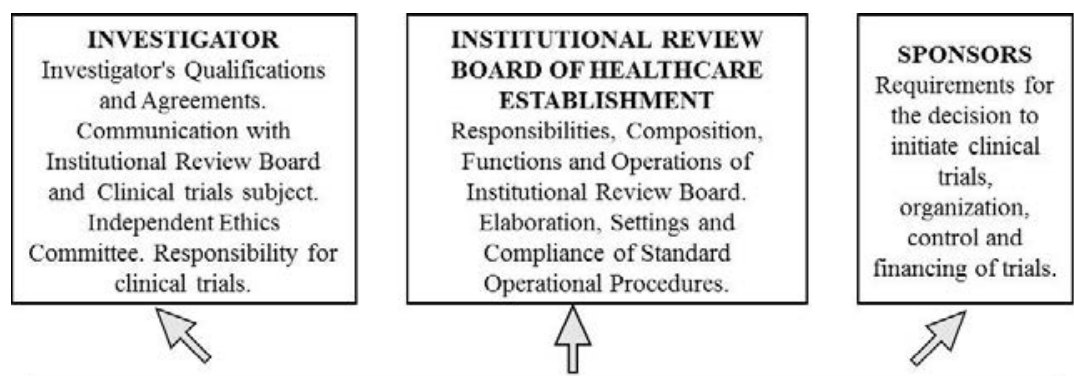

EMA/CHMP/ICH/135/1995, Committee for Human Medicinal Products, Guideline for good clinical practice - ICH E6 (R2), 2016
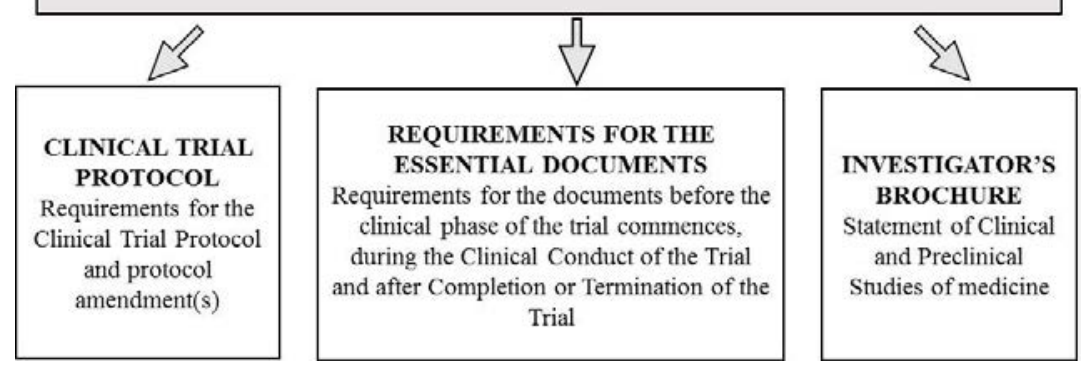

Fig. 4. Structure of Guidelines "Medicines. Good Clinical Practice. 42-7.0:2008”, developed by a student of second cycle of education program Spreys $D$. 


\section{Conclusion and suggestions}

1. A retrospective review of the curriculum has been carried out; the current educational process for specialty 226 "Pharmacy, Industrial Pharmacy", which takes place at the Lviv Polytechnic National University, has been analyzed.

2. The discipline "Good Practices in Pharmaceutics" includes the whole range of practices, so it is proposed at the Lviv Polytechnic National University for study at the third (educational-scientific) level.

3. Structural-and-logical schemas based on the Guidelines of Good Pharmaceutical Practices that greatly facilitate students' perception and assimilation of all the needed information have been elaborated.

4. The study of the possibility of mastering the discipline "Good Practices in Pharmaceutics" by students of specialty 226 "Pharmacy, Industrial Pharmacy" during the practice at the existing pharmaceutical enterprises can be considered perspective.

\section{References}

On approval of the Guidelines "Good Pharmaceutical Practice. Pharmacy service quality standards”. (2013). Order Ministry of Health care of Ukraine. No 455, 30.05.2013. Kyiv. [In Ukrainian].

Lebedinets, V, Tkachenko, O, Gubin, Yu, Zborovskaya, T, Romelashvili, O, Spiridonov, N. (2017). Good Practices in Pharmacy: Textbook. Kharkiv. [In Ukrainian].

Hudz, N, Kalynyuk, T, Bilous, S, Smetanina, K. (2013). Good Practices in Pharmacy: Textbook. Vinnytsya. [In Ukrainian].

Krychkovs'ka, A, Zayarnyuk, N, Bolibrukh, L. (2017). Developing a complex of Good Pharmaceutical Practices for Good Pharmaceutical Education. Implementation of Good Practices in Pharmacy: achievements, perspectives and challenges. 45-54.

Hromovyk, B, Horilyk, A. (2013). Situational analysis of pharmaceutical education in Ukraine. Currents in Pharmacy Teaching and Learning. Vol. 5(3). 191-200.

Abdellah, A, Noordin, M, Ismail, W. (2015). Importance and globalization status of good manufacturing practice (GMP) requirements for pharmaceutical excipients. Saudi Pharmaceutical Journal. Vol. 23(1). 9-13.

Mitroka, J, Harrington, C, DellaVecchia, M. (2020). A multiyear comparison of flipped-vs. lecture-based teaching on student success in a pharmaceutical science class. Currents in Pharmacy Teaching and Learning. Vol. 12(1). 84-87.

Law, M, Bader, L, Uzman, N, Williams, A, Bates, I. (2019). The FIP Nanjing Statements: Shaping global pharmacy and pharmaceutical sciences education. Research in Social and Administrative Pharmacy. Vol. 15(12). 1472-1475.

Patel, K, Chotai, N. (2008). Pharmaceutical GMP: past, present, and future-a review. Die Pharmazie-An International Journal of Pharmaceutical Sciences. Vol. 63(4). 251-255. doi: 10.1691/ph.2008.7319.

Koster, A, Schalekamp, T, Meijerman, I. (2017). Implementation of Competency-Based Pharmacy Education (CBPE). Pharmacy. Vol. 5(1). 10-26. doi:10.3390/pharmacy5010010.

Pearson, M, Hubball, H. (2012). Curricular Integration in Pharmacy Education. American Journal of Pharmacy Education. Vol. 76. 204-220. doi: 10.5688/ajpe7610204.

Meijerman, I, Nab, J, Koster, A. (2016). Designing and Implementing an Inquiry-Based 
Undergraduate. Currents in Pharmacy Teaching and Learning. Vol. 8. 905-919. doi: 10.1016/j. cptl.2016.08.001.

Ten Cate, O, Scheele, F. (2007) Viewpoint: Competency-Based Postgraduate Training: Can We Bridge the Gap between Theory and Clinical Practice? Academic Medicine. Vol. 82. 542-547. doi: 10.1097/ACM.0b013e31805559c7

Pittenger, A, Chapman, S, Frail, C, Moon, J, Undeberg, M, Orzoff, J. (2016). Entrustable Professional Activities for Pharmacy Practice. American Journal of Pharmaceutical Education. Vol. 80, 57-65. doi:10.5688/ajpe80457.

Medicines. Good Manufacturing Practice. Guidelines. 42-4.0:2015. (2015). Kyiv. [In Ukrainian]. Medicines. Good Distribution Practice. Guidelines. 42-5.0:2014. (2014). Kyiv. [In Ukrainian]. Medicines. Good Laboratory Practice. Guidelines 42-6.0:2008. (2009). Kyiv. [In Ukrainian]. Medicines. Good Clinical Practice. Guidelines. 42-7.0:2008. (2009). Kyiv. [In Ukrainian]. Medicines. Good Storage practice. Guidelines. 42-5.1:2011. (2011). Kyiv. [In Ukrainian]. 